\title{
A STUDY ON SEASONAL VARIATION OF TOURIST ARRIVAL IN NEPAL Basanta Dhakal
}

\begin{abstract}
Seasonality is one of the most important factors in the tourism industry in Nepal. Economically, it can have many negative influences as a destination, but at the same time it may give a time for improvement of services provided by host community as well as it may recover to the service providers from the stress of the peak season. This paper highlights the pattern of seasonal variation of tourist arrival in Nepal at different time on the monthly and quarterly basis. It is found that the seasonal variation is the maximum in autumn (128.801) and minimum in summer (81.857). Similarly it is the maximum in October (157.27) and minimum in June (68.68). This paper also tries to present annual increase of number of tourists that is 37,089 in number per year. This study expects that the findings of this paper may help planners and decision makers for formulating tourism policies and programs of the nation.
\end{abstract}

Key words: Annual Increase, Seasonal Variation, Tourist Arrival.

\section{INTRODUCTION}

Tourism is the temporary movement of people to destination outside their normal places of work and residence, the activities undertaken during their stay in those destinations, and the facilities created to their needs. It includes a wide array of people, activities and facilities. Although tourism is not a distinctly identified industry, most people would agree that it is a unique grouping of industries that are tied together by a common denominator-the traveling public. "Tourism appears to be becoming an acceptable term to singularly describe the activity of people taking trips away from home and the industry which has developed in response to this activity"(Waters, 1990: 26).

Various efforts have been made for the development of tourism in Nepal. Modern tourism had begun in Nepal after the first ascent by Edmund Hillary and Tenzing Norgay in 1953. The publicity made by the historical ascent of Mt. Everest in international arena. Similarly in 1953, Nepal got the membership of United Nations Organization (UNO) and Non-aligned Countries' group; it was very easy for Nepal to be introduced in the world arena. During this period, Nepal made concrete efforts to develop tourism in Nepal, created necessary institutional infrastructure needed to promote tourism, beginning from the establishment of Tourism Development Board in 1957.The Department of Tourism and Ministry of Tourism were established in 1959 and 1977 respectively. In this respect, notable efforts were the Tourism Master Plan 1972, Review of the Master Plan 1984, and defining Tourism Policy in 1995 (Shrestha,1998). Nepal has already organized the Visit Nepal year 1998, Tourism Year 2011 and Visit Lumbini Year 2012 to promote the tourism industries.

Mr. Dhakal is an Associate Professor, Nepal Commerce Campus, T.U., Kathmandu, Nepal. 
The term seasonality refers to the intra year fluctuations of a given variable or indicator to the extent that such fluctuation is a reasonable effect and may be either indirectly or entirely unobservable. Any variable that demonstrates a fairly predictable and regular intra year pattern of fluctuation is said to exhibit seasonal tendency (Berstein, 1998). It introduces a number of issues that require special attention and strategies which affect the number of tourists coming to the business region and adding to the viability of the business region (Lee, Bergin and Graeme, 2008). It means changes in business, employment or buying patterns which occurs regularly during a year as a result of changes in climate holidays and vacations.

Seasonality is one of the most distinctive features of tourism and it is a most typical characteristic of tourism on a global basis after the movement of people on temporary basis (Baum and Lundtorp, 2001: 5). Seasonality can also be defined as temporal imbalance in the phenomenon of tourism, which may be expressed in terms of dimensions of such elements as numbers of visitors, employment and admissions to attractions. Seasonality notes two basic origins of the phenomenon that is natural and institutional. Natural seasonal variation is the result of regular variation in climatic increases according to distance from the equator. Institutional seasonal is the result of human decisions and is much more widespread and less predictable than natural seasonality. It is the outcome of combination of religious, worship, holidays or pilgrimages and industrial holidays are good examples of institutional seasonal variation in demand for tourism services.

Nepal, located in South Asia, is one of the small countries in the world. It is situated between big countries like India and China. It is land locked; specially called India locked country, because only north side is bounded by China, other three sides bounded by India.

Now a days, tourism has became one of the top foreign currency earning sectors in Nepal. In 2007/2008, it has generated Rs. 18.365 billion which was $84.2 \%$ of the total foreign exchange earnings. It provides a significant contribution to GDP along with generating employment sectors such as hotel, restaurant, traveling, handicraft etc as indirect contribution. It has also contributed in popularizing Nepal to the world (Dhakal, 2010: 32). Nepal is shown to be an effective and promising instrument for earning foreign exchange, but also one that requires high investment, both public and private while providing relatively few jobs and offering little scope for the improvement of personal and regional income distribution. It, therefore, suggested developing tourism to the extent that exchange is needed for development purpose but to concentrate society's resources in other field where benefits of developments are shared more widely (Berger, 1978).

Seasonality factor has been found most prominent in Nepalese tourism. Expenditure on food items has been found inelastic where as that of travel elastic. Weighted GDP of the tourist organizing countries is found elastic and significant. Direct, indirect and induced effects of tourism sector on value added have been relatively larger than those of the non tourism sectors (Dungel, 1981).

The net earnings from tourism were greater than from some sectors of the economy. The economic impact of tourism can be enhanced by promoting standard hotels instead of low quality hotels serving low paying tourists. Nepal must go for high -paying tourists. The economic Impact can also be increased by 
developing substitutable industries and increasing the supplying capacity of the critical sectors. In Nepal, summer season is less suitable for western tourists but it is very suitable for Japanese, Indians, Thai and other Asians. Furthermore the Asian market is closer and therefore traveling cost is less and most of these economies are growing (Khadka, 1993).

The leakage of foreign exchange earnings, high import contents, seasonal fluctuations in demand for tourism and over dependence on seasonality factor have been the major weakness in the tourism industry of Nepal. Tourism related policies and sectors like infrastructure, open-sky policy, planning of new tourism project, opening of a new destination in the country, tourism marketing strategy, management of travel agencies, full capacity utilization of hotels etc, should be planned properly (Pradhananga,1993).

Therefore, tourism industry is such a sector that can generate more jobs by making low investment as compare to other sectors. It is not related to a certain group of people but it covers the people to all walks of life in the society. For example, the migration of workers to the Middle East Region can be controlled through the development of tourism industry. It unites not only the regions but also the people globally. Tourism is not only the limited commercially but it should be adopted as a process of life. In this respect, it needs to study the seasonal variation of tourist arrival in Nepal at different time on the monthly and quarterly basis, which may help to planners and decision makers for formulating tourism policies and programs of the nation.

\section{MATERIALS AND METHODS}

The present study is analytical and descriptive in nature, which is based in published source of secondary data. The data for the analysis of this study is taken from Annual Report (2010/11) of Ministry of Tourism and Civil Aviation (MTCA), Statistical Year book of Nepal 2009 (CBS), Nepal in Figure 2010 (CBS), Nepal Tourism Board (2012), and other different associations, which are related with tourism. The number of tourist arrival (yearly, quarterly and monthly) is the main variable of this study. Some descriptive statistics such as mean, percentage, standard deviation (S.D.), coefficient of variation (C.V.), skewness and kurtosis are used to compare the number of tourist arrival in different seasons and months. Seasonal index by simple average method is adopted to assess the current trend and tendency of tourist arrival in different seasons (quarters) and months. Trend analysis by least square method is used to find the yearly as well as quarterly and monthly increment of tourist. Software tool, which is used is SPSS package.

\section{RESULTS AND DISCUSSIONS}

In the real sense, the development of tourism started in Nepal from the beginning of 1960's. During the period, Nepal became a popular center for Hippies. Since 1962, Nepal Government/Department of Tourism started to take tourism statistics. The tourism statistics has been started from 1963. Table 1 shows the number of total tourist arrival and its percentage change from 2001 to 2011. 
Table 1: Tourist Arrival in Nepal during the Period 2001-2011

\begin{tabular}{|c|c|c|}
\hline Year & $\begin{array}{c}\text { Total Number of } \\
\text { Tourist }\end{array}$ & Percentage Change \\
\hline 2001 & 361237 & - \\
\hline 2002 & 275468 & -23.74 \\
\hline 2003 & 338132 & 22.75 \\
\hline 2004 & 385297 & 13.95 \\
\hline 2005 & 375398 & -2.22 \\
\hline 2006 & 383926 & 2.27 \\
\hline 2007 & 526705 & 37.19 \\
\hline 2008 & 500277 & -5.02 \\
\hline 2009 & 509956 & 1.93 \\
\hline 2010 & 602867 & 18.22 \\
\hline 2011 & 735934 & 22.07 \\
\hline
\end{tabular}

Source: NTB, 2012.

From the above table, the trend line equation is $\mathrm{Yc}=454108.8+37089.27 \mathrm{X}$ which is the line of best fit. The Y-intercept (a) $=454108.8$ which is the value of $\mathrm{Y}$ when $X=0$. The rate of change of number of tourist for unit change of time in a year (b) $=37089.27$ which is the annual increases of number of tourist arrival in Nepal. It indicates that in each year, the number of tourist is increased by 37,089 . The percentage change of tourist arrival is negative in the years 2002, 2005 and 2008 but in the remaining years, it is positive.

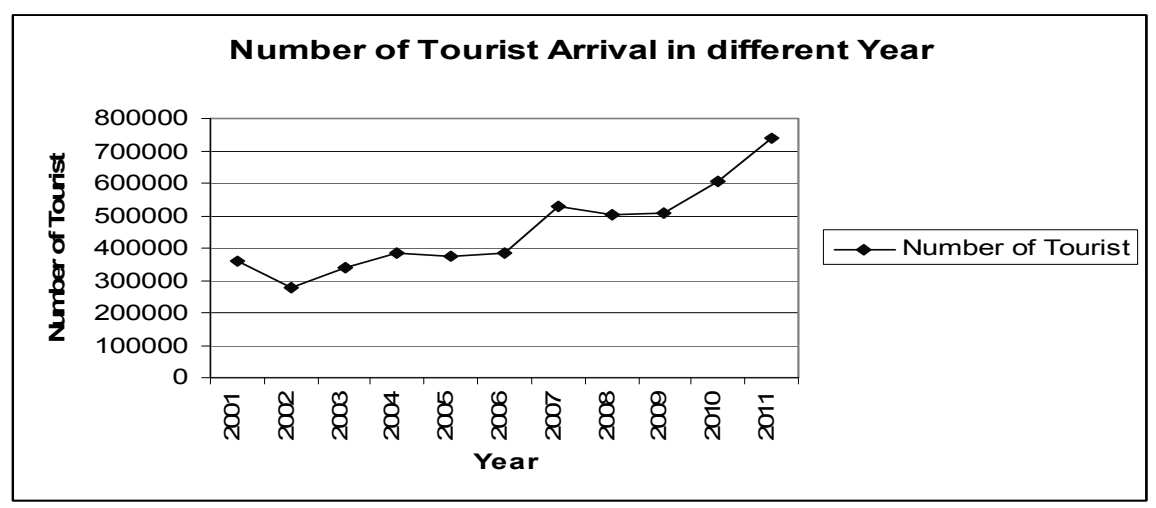

Figure: 1

Figure 1 shows that the maximum tourist arrival in 2011, and minimum in 2002. In the years 2004, 2005 and 2006, there is no any significant difference of tourist arrival. From the year 2009, the number of tourist arrival is directly going to upward projection.

There are four seasons in the year viz. winter, spring, summer and autumn. Winter includes the months of December, January and February, spring includes the months of March, April and May, summer includes the months of June, July and August, and autumn includes the months of September, November and October. The number of tourist arrival in Nepal is not homogeneous among 
the different seasons. Seasonality plays the more important role about it. Table 2 shows the average number of tourist arrival in Nepal in different seasons as well as seasonal variation, coefficient of variation, skewness, kurtosis and annual increases of number of tourist arrival in Different seasons from 2001 to 2011.

Table 2: Tourist Arrival in Different Seasons

\begin{tabular}{|l|c|c|c|c|}
\hline \multicolumn{1}{|c|}{ Year } & Winter & Spring & Summer & Autumn \\
\hline 2001 & 87722 & 114137 & 56681 & 102697 \\
\hline 2002 & 62834 & 69955 & 54932 & 87747 \\
\hline 2003 & 78679 & 76292 & 70580 & 112581 \\
\hline 2004 & 97626 & 104606 & 77815 & 105250 \\
\hline 2005 & 83985 & 78830 & 83514 & 129069 \\
\hline 2006 & 90506 & 81726 & 84543 & 127151 \\
\hline 2007 & 115282 & 131518 & 111436 & 168469 \\
\hline 2008 & 122428 & 127620 & 89787 & 160422 \\
\hline 2009 & 110944 & 122941 & 106355 & 169716 \\
\hline 2010 & 133317 & 141109 & 126926 & 201515 \\
\hline 2011 & 158994 & 173440 & 159657 & 243843 \\
\hline Average & 103847 & 11106.7 & 92929.64 & 146223.6 \\
\hline Seasonal Index & 91.474 & 97.868 & 81.857 & 128.801 \\
\hline $\begin{array}{l}\text { Standard } \\
\text { Deviation }\end{array}$ & 27609.32 & 32368.07 & 31281.99 & 47558.19 \\
\hline C.V. & $26.586 \%$ & $29.132 \%$ & $33.662 \%$ & $32.524 \%$ \\
\hline Skewness & 0.592 & 0.406 & 0.905 & 0.824 \\
\hline Kurtosis & 0.133 & -0.435 & 0.703 & 0.146 \\
\hline $\begin{array}{l}\text { Annual } \\
\text { increase(b) }\end{array}$ & 7418.07 & 7452.67 & 8745.60 & 13472.28 \\
\hline
\end{tabular}

Source: NTB, 2012.

The above table shows that the average numbers of tourist arrival are $103847,111107,92930$, and 146224 in the seasons of winter, spring, summer and autumn respectively. The maximum number of tourist arrival in autumn season, second and third positions is in spring and winter season but least tourist arrival in summer season. The seasonal indices of winter, spring, summer and autumn are 91.474, 97.868, 81.857 and 128.801 respectively. There is maximum seasonal variation in autumn but minimum in summer. The lowest coefficient of variation in winter season shows that the number of tourist arrival in this season is more uniform than the other seasons. But there is maximum variation in summer season. The positive values of skewness in all seasons indicate the number of tourist arrival in Nepal is positively skewed. The negative value of kurtosis shows the number of tourist arrival in spring season is flatter (platykuric) in nature. The annual increases of tourist are 7418.07, 7452.67, 8745.60 and 13472.28 in the seasons of winter, spring, summer and autumn respectively. In the autumn season, there are maximum annual increases of tourist. But in the winter season, there are minimum annual increases of tourist in Nepal. 


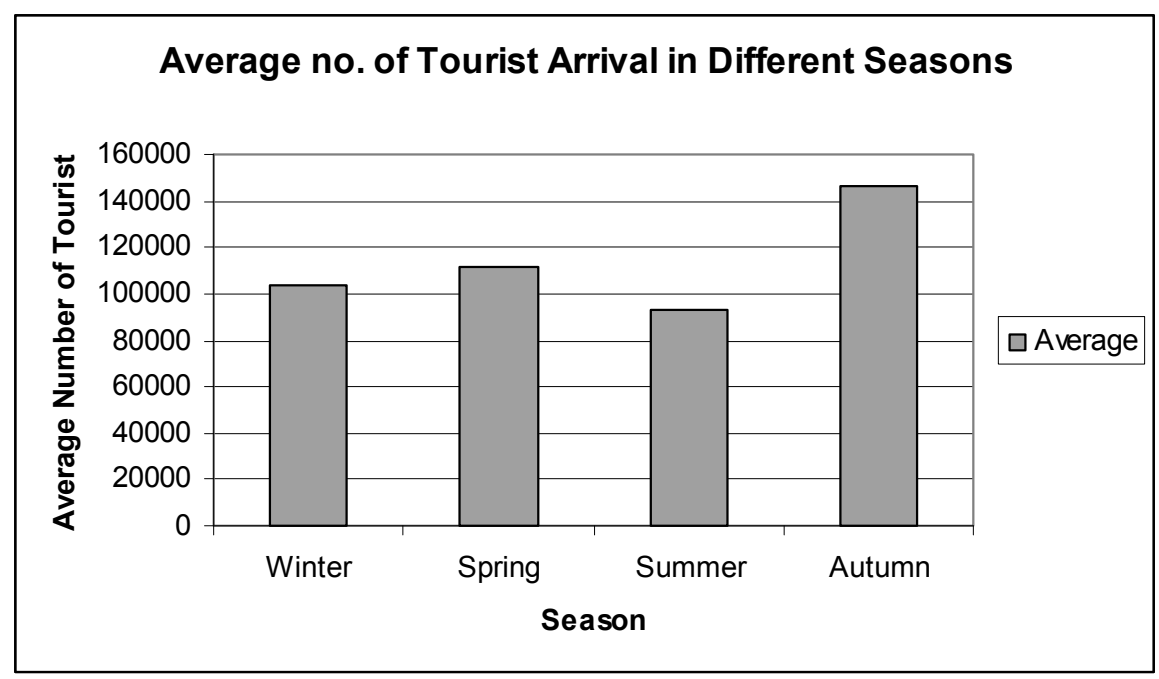

Figure: 2

Figure 2 shows that autumn is the peak season of tourist arrival in Nepal. The second and third choices of tourists are spring and winter seasons respectively. But summer season is the least choice of tourists. So autumn is the most favorable season with compare to others.

Table 3 shows the average number of tourist arrival in Nepal in different months. It also shows the seasonal variation of tourist arrival in different months and gives the detail analysis of descriptive statistics like standard deviation, coefficient of variation, skewness, kurtosis and annual increases of tourist in twelve months from 2001 to 2011 . The monthly arrival of tourist is given in the annex table below.

Table 3: Tourist Arrival in Different Months

\begin{tabular}{|l|c|c|c|c|c|c|c|}
\hline Month & Average & S.I. & S.D. & C.V. (\%) & Skewness & Kurtosis & $\begin{array}{c}\text { Annual } \\
\text { Increase } \\
\text { (b) }\end{array}$ \\
\hline Jan. & 29973.27 & 79.20 & 7057.75 & 23.48 & -0.151 & 0.402 & 1548.68 \\
\hline Feb. & 36202.09 & 95.66 & 12119.63 & 33.48 & 0.078 & -1.112 & 2846.97 \\
\hline March & 46173.91 & 122.01 & 14074.28 & 30.48 & 0.025 & -1.344 & 3275.58 \\
\hline April & 35735.00 & 94.43 & 11949.50 & 33.43 & 0.494 & -0.058 & 2546.70 \\
\hline May & 29197.91 & 77.15 & 4313.83 & 28.13 & 1.119 & 2.013 & 1630.40 \\
\hline June & 25991.09 & 68.68 & 9190.86 & 35.36 & 0.857 & 1.029 & 2555.62 \\
\hline July & 27658.27 & 73.08 & 8229.87 & 29.76 & 0.594 & -0.587 & 2229.48 \\
\hline August & 39280.27 & 103.80 & 14358.60 & 36.55 & 1.076 & 1.366 & 3502.20 \\
\hline Sept. & 38588.36 & 101.97 & 11934.35 & 30.92 & 0.656 & -0.362 & 3254.16 \\
\hline Oct. & 59514.45 & 157.27 & 19631.47 & 32.98 & 0.740 & -0.116 & 4234.37 \\
\hline Nov. & 48133.64 & 127.19 & 16387.88 & 34.04 & 0.993 & 0.840 & 4653.40 \\
\hline Dec. & 37671.64 & 99.54 & 1135.10 & 30.124 & 0.336 & 0.673 & 3204.23 \\
\hline
\end{tabular}

Source: Annex-1.

Table 3 shows that the average number of tourists arrival in Nepal are 29973, 36202, 46174, 35735, 29198, 25991, 27658, 39280, 38588, 59514, 48134, 37672 in the months of January, February, March, April, may, June, July, August, 
September, October, November and December respectively. The maximum number of tourist flow in the month of October but least in June. The seasonal indices in the different months are 79.20, 95.66, 122.01, 94.43, 77.15, 68.68, $73.08,103.80,101.97,157.27$, and 99.54 respectively. The maximum seasonal variation occurs in October but minimum in June. The maximum coefficient of variation is in November but least in January. The negative value of skewnness in January shows that the model value of number of tourist is greater than average number of tourist arrival in that month. The negative values of kurtosis in the months of February, March, April, July, September and October indicate that the distribution of tourist arrival is platykurtic in nature in that months. The positive values of kurtosis in the months of January, May, June, August, November, and December indicate the distribution of tourist arrival is leptokurtic in nature in that months. The annual increases of tourist arrival are 1549, 2847, 3276, 2547, 1630, 2556, 2229, 3502, 3254, 4234, 4653 and 3204 in the months of January, February, March, April, may, June, July, August, September, October, November and December respectively. The maximum annual increases of tourist arrival are in the month of November but least in January.

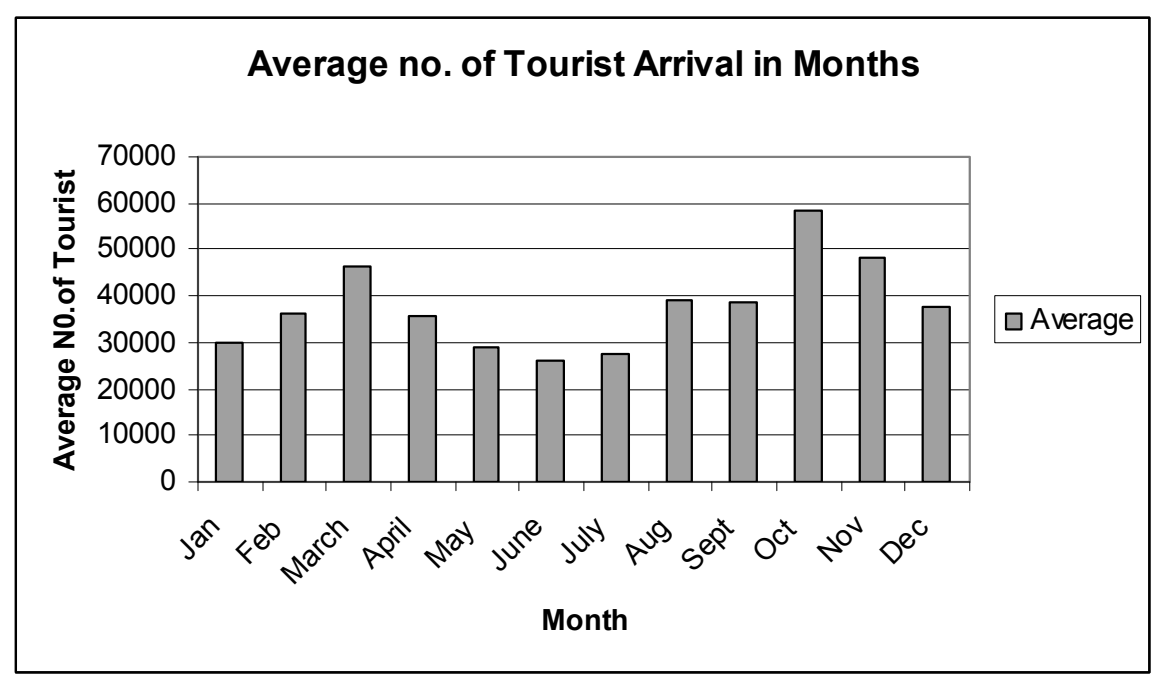

Figure: 3

Figure 3 shows that most preferred month by tourist is October. Similarly second and third choices are November and March respectively. The months May, June and July are least preferred by tourist. The months December, January, February, April, August and September is the moderately preferred by the tourists.

\section{CONCLUSION}

Tourism has been playing a pivotal role in the socio-economic sectors of the developed as well as developing countries of the globe. So most of the nations are attracted to this industry and trying their best to strengthen economic life by promoting tourism in the country. Tourism has been identified as an important source of foreign exchange earnings, as an industry creating employment opportunities and generating economic growth of the country. Nepal has the 
richest and most diversify socio-cultural landscapes. It is the holy land of Hindus and Buddhist where they have lived together in great harmony for the centuries. With possession of such numerous attractions, the potentiality of tourism is very high in Nepal but Proper strategic plan is necessary to develop tourism market throughout the world.

The seasonal index of tourist arrival is the maximum in autumn (128.801) and minimum in summer (81.857). Similarly it is the maximum in October (157.27) and minimum in June (68.68). Autumn is the most preferred season and October and November are most preferred months by tourists. The dry season has only started and monsoon has just finished in that months. At this season, the visibility is clear and the views of Himalayan are as near perfect in the mountain region. Rice is harvested in the terai and hilly regions. Some colorful festivals are celebrated in those months as well as the weather is still balmy, neither too hot nor too cold. So that October is the first peak season and November is the second peak season of tourist in Nepal. The annual increase of tourists in the autumn season is 13472 per year. Similarly, it is 4234 and 4653 in the months of October and November respectively. The number of tourist is increased by 37,089 per year in Nepal. Similarly, it is increased by 3,091 per month. So, Nepal as an important destination internationally but it is needed to priorities international publicity and promotion.

\section{WORKS CITED}

Baum, T .and Lundtorp, S. (2001). Seasonality in tourism. Oxford Press, UK.

Berger, V. (1978). The Economic impact of tourism in Nepal (Doctoral Thesis). Faculty of the Graduate School, Cornell University, USA.

Bernstein, J. (1998). Seasonality: System, strategies and signals. Oxford Press, UK.

CBS (2009). Statistical Year Book of Nepal, Central Bureau of Statistics, Kathmandu, Nepal.

CBS (2010). Nepal in figure. Central Bureau of Statistics, Kathmandu, Nepal.

Dhakal, B. (2011). "Shangri-La tourism: Challenges and prospects." Pragamanch: A Journal of Tribhuvan University. Teachers' Association, P.N. Campus. 25(11) 199-203.

Dhakal, D.P. (2010). Nepal Tourism Statistics. NEPSA Digest: Official Publication of Nepal Statistical Association, pp. 32-36.

Dhungel, R. (1981). Economics of tourism in Nepal, Kathmandu: Development Research and communication Group.

Khadka, K.R. (1993). Tourism and economic development in Nepal (Doctoral Thesis). Development and Project Planning, University of Bradford, UK.

Lee, C., Bergin S. and Graeme, G. (2008). Seasonality in tourism industry: Impact and strategies. Retrieved from http:// www.sustainabletourismonline.com.

MTCA (2010). Nepal tourism statistics 2010. Ministry of Tourism and Civil Aviation, Kathmandu. 
NTB (2012). Tourist arrival. Nepal Tourism Board, Kathmandu, Nepal.

Pradhananga, S.B. (1993). Tourist consumption pattern and Its economic impact of Nepal (Doctoral Thesis). Central Department of Economics, Tribhuvan University, Kathmandu.

Shrestha, H.P. (1998). Tourism marketing in Nepal, (Doctoral Thesis). Faculty of Management, Tribhuvan University, Kathmandu.

Tewari, S.P. (1994). Tourism dimensions. Atma Ram and Sons, Delhi.

Waters, S. (1990). The US travel industry: Where we're going. The cornel Hotel and Restaurant Administration, Quarterly, USA.

WTTC. (2012). Travel and tourism's economics perspective. World Travel and Tourism Council, Brussels. 
ANNEX-1

Tourist Arrival in Different Months (2001-2011)

\begin{tabular}{|c|l|c|c|c|c|c|c|c|c|c|c|c|}
\hline Year & Jan. & Feb. & March & April & May & June & July & Aug. & Sept. & Oct. & Nov. & Dec. \\
\hline 2001 & 30545 & 38680 & 46709 & 39083 & 28345 & 13030 & 18329 & 25322 & 31170 & 41245 & 30282 & 18588 \\
\hline 2002 & 17176 & 20668 & 28815 & 21253 & 19887 & 17218 & 16621 & 21093 & 23752 & 35272 & 28723 & 24990 \\
\hline 2003 & 21215 & 24349 & 27737 & 25851 & 22704 & 20351 & 22661 & 27568 & 28724 & 45459 & 38398 & 33115 \\
\hline 2004 & 30988 & 35631 & 44290 & 33514 & 26802 & 19793 & 24860 & 33162 & 25496 & 43373 & 36381 & 31007 \\
\hline 2005 & 25477 & 20338 & 29875 & 23414 & 25541 & 22608 & 23996 & 36910 & 36066 & 51498 & 41505 & 38170 \\
\hline 2006 & 28769 & 25728 & 36873 & 21983 & 22870 & 26210 & 25183 & 33150 & 33362 & 49670 & 44119 & 36009 \\
\hline 2007 & 33192 & 39934 & 54722 & 40942 & 35854 & 31316 & 35437 & 44683 & 45552 & 70644 & 52273 & 42156 \\
\hline 2008 & 36913 & 46675 & 58735 & 38475 & 30410 & 24349 & 25427 & 40011 & 41622 & 66421 & 52399 & 38840 \\
\hline 2009 & 29278 & 40617 & 49567 & 43337 & 30037 & 31749 & 30432 & 44174 & 42771 & 72522 & 54423 & 41049 \\
\hline 2010 & 33645 & 49264 & 63058 & 45509 & 32542 & 33263 & 38991 & 54672 & 54848 & 79130 & 67537 & 50408 \\
\hline 2011 & 42599 & 56339 & 67532 & 59724 & 46184 & 46015 & 42304 & 71338 & 61109 & 99304 & 83430 & 60056 \\
\hline
\end{tabular}

Sources: NTB, 2012. 